\title{
Nisus steps forth
}

\author{
David Goldblatt, MD
}

Meanings that Roman authors gave to nisus (NYsus), a word chiefly used in poetry, ranged from the pedestrian (a step or tread) to the celestial (the course of the stars). Cicero, Horace, Vergil, and others used nisus to convey striving, endeavor, ascent, flight, and the pain of giving birth..$^{1,2}$

In this issue of Neurology, a new feature, Nisus, steps forth, to link neurology and neurologists with philosophy and literature-areas of learning concerned with thought and human relations-and with the arts. In Nisus, readers will find poems, short fiction, and creative nonfiction replete with illustration, imagery, scenes, and dialogue. There will be essays that draw upon the personal history of the writer and memoirs that provide personal insight concerning important topics. There will be a focus on neurologic themes in the broader context of medicine and society.

We urge you, our readers, to help us in various ways: to send us your own creative writing for publication, to encourage contributions from qualified writers both within and outside the AAN, to volunteer to perform peer review under my supervision as Nisus Editor, and to share your comments and opinions concerning this new direction for the journal. Your participation will determine its success.

In 2000 and again this year, the American Academy of Neurology (AAN) awarded a $\$ 2,000$ prize for Creative Expression of Human Values in Neurology: $\$ 500$ to the winner and $\$ 1,500$ to a charity of the winner's choice. The award recognizes creative writing that inspires understanding of and compassion for those suffering from neurologic disorders. Each year, approximately 30 AAN members submitted either short fiction or poetry that was judged for its focus on human values in the doctor-patient relationship, its originality and creativity, its potential to change for the better the way neurology is practiced and the outcome of care for neurologic patients, its artistry and skill of presentation, and its ability to communicate to the reader.

The judges-all of them published writers-were either physicians or persons with neurologic conditions. Michael A. LaCombe, who edits "On Being a Doctor" for Annals of Internal Medicine, and I judged both competitions. John Stone, dean, cardiologist, and distinguished poet, judged the contest in 2000 . Floyd Skloot, who judged both this year and last, has been able to continue a career as a writer of awardwinning novels and poetry despite contending for more than a decade with serious consequences of encephalitis. Many of his poems have appeared in the Journal of the American Medical Association. June Price, who became a judge this year, founded and until recently edited Living SMArt, a newsletter by and for adults with spinal muscular atrophy, a condition she has had since infancy. She has also written a book to help disabled individuals live independently. Her insights are worth the time of neurologists, even those of us who may have thought we knew all about caring for severely weak patients.

The winner of the 2000 competition was Dr. Peter B. Kang, who was then a resident in pediatric neurology at the University of Pennsylvania. His story, "Playing Hooky," about a routine office visit and what did and did not happen on that day, is an appropriate introduction to Nisus. ${ }^{3}$ In forthcoming issues, we will publish this year's winning story, other notable contributions to the contest, and material newly submitted to Nisus. Some new submissions may be guided by the precepts of the Human Values award. Many, we hope, will take new directions.

No line separates fact from fiction. Everyone's fiction is someone's fact and tomorrow's fact is today's fiction. Nonetheless, the uses of fact and fiction are distinct and, if possible, a distinction should be made. In 1988, an anonymous account of giving a lethal dose of morphine to a dying patient appeared in the Journal of the American Medical Association. ${ }^{4}$ The story, which became notorious, was not verified and may or may not be true. That uncertainty is important: there is a difference between reporting one's personal act of euthanasia-performed, however misguidedly, out of compassion for sufferingand contriving a polemic against euthanasia in the guise of a case report that is actually false.

Nisus intends to avoid such ambiguous situations: authors will publish under their own names and will be asked to label their prose submissions as fiction,

$\overline{\text { See also page } 562}$

Professor Emeritus of Neurology and of the Medical Humanities, University of Rochester School of Medicine and Dentistry, NY.

Address correspondence and reprint requests to Dr. David Goldblatt, 232 East Lake Road, Penn Yan, NY 14527; e-mail: dgoldblattmd@flare.net 
essay, personal history, or memoir. If a work of fiction is based on fact, it will be important to disguise identities that should not be inadvertently revealed. If persons are identified within factual material, it will be the responsibility of the author to secure their permission when that is appropriate. Usually, it will be better to change names and identifying particulars. Doing so will not change fact to fiction.

To achieve and maintain a high quality, Nisus is seeking qualified reviewers. If you are both someone familiar with neurology and a published author of poetry or prose of the type suitable for Nisus, we would like you to volunteer your services.

If you have written poetry or prose suitable for Nisus that has not been submitted elsewhere, or are in the process of doing such work, we hope that you will consider publication in Neurology. We invite all our readers to foster their creativity. We need evi- dence of interest and many outstanding submissions to decide how often this new feature should appear. We anticipate that only a minority of submissions will be accepted for publication, but we are more than willing to be pleasantly surprised.

We expect to hear from you if you share our belief that the most effective way to survive the everincreasing pressures of our professional lives is not to narrow our focus but to enlarge our horizons-to look up, from time to time, from our footsteps to the stars.

\section{References}

1. Andrews EA, ed. Harper's Latin dictionary. New York: American Book Company, 1907.

2. Marchant JRV, Charles JF, eds. Cassell's Latin dictionary. New York: Funk \& Wagnalls, 1946.

3. Kang PB. Playing hooky. Neurology 2001;57:562-564.

4. Anonymous. It's over, Debbie. JAMA 1988;259:272. 


\title{
Neurology
}

\author{
Nisus steps forth \\ David Goldblatt \\ Neurology 2001;57;381-382 \\ DOI 10.1212/WNL.57.3.381
}

This information is current as of August 14, 2001

\section{Updated Information \& Services}

\section{References}

Citations

Permissions \& Licensing

Reprints including high resolution figures, can be found at: http://n.neurology.org/content/57/3/381.full

This article cites 1 articles, 1 of which you can access for free at: http://n.neurology.org/content/57/3/381.full\#ref-list-1

This article has been cited by 1 HighWire-hosted articles: http://n.neurology.org/content/57/3/381.full\#\#otherarticles

Information about reproducing this article in parts (figures,tables) or in its entirety can be found online at:

http://www.neurology.org/about/about_the_journal\#permissions

Information about ordering reprints can be found online:

http://n.neurology.org/subscribers/advertise

Neurology ${ }^{\circledR}$ is the official journal of the American Academy of Neurology. Published continuously since 1951, it is now a weekly with 48 issues per year. Copyright . All rights reserved. Print ISSN: 0028-3878. Online ISSN: 1526-632X.

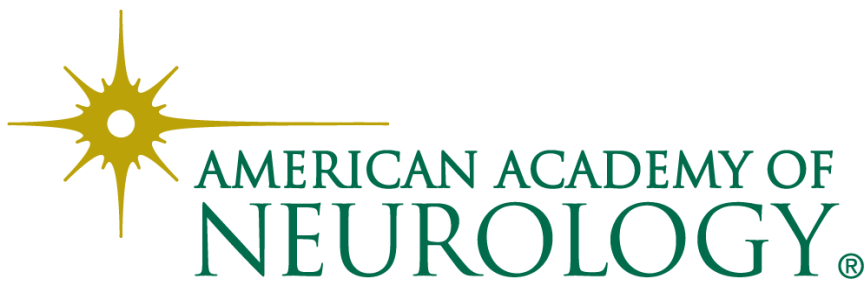

